\title{
The profile of Dentistry students at Federal University of Rio Grande do Sul and expectations regarding the profession, 2010-2011
}

\author{
O perfil do formando em Odontologia da Universidade Federal do Rio Grande do Sul e expectativas \\ quanto à profissão, 2010-2011
}

Fernando Stumpf BÖCKMANN ${ }^{1}$

Bruna Barnard MOTTA ${ }^{1}$

Jerônymo Maciel CAMARGO'

Paulo Cauhy PETRY2

Ramona Fernanda Ceriotti TOASSI ${ }^{2}$

\section{ABSTRACT}

\section{Objective}

We analyze the socio-demographic profile of the dentistry graduates at the Universidade Federal do Rio Grande do Sul, 2010-2011, the reasons which led them to choose Dentistry, appreciation for the course, as well as job prospects and Graduate studies.

\section{Methods}

Cross-sectional, observational study Dentistry graduates, classes of 2010-2/ 2011-1 ( $n=76,90.5 \%$ response rate). Data collection took place through the giving of a structured and anonymous pre-tested questionnaire. Results were grouped in tables and graphs by means of the distribution of the frequency of variables studied (descriptive analysis), with the assistance of the Statistical Package for the Social Sciences (SPSS) for Windows 17.0. This Study was approved by the Committee on Ethics in Research of the Universidade Federal do Rio Grande do Sul (18249).

\section{Results}

The classes of 2010-2/ 2011-1 Dentistry Graduates of the Universidade Federal do Rio Grande do Sul, were, in their majority, women, young, single, childless, natives of the State of Rio Grande do Sul, with a monthly salary income of 10 to 20 minimum salaries and without the presence of dentists in the family. More than $90 \%$ of these students were satisfied with the choice of Dentistry. They opted for the course especially due to personal as well as professional success, followed by security and peace of mind and financial comfort. The great part of the students evaluated the course as good or excellent. They intend, as a majority, to work in the public service as well as private practice and graduate work, particularly, specialization.

\section{Conclusion}

Results identified the profile of the classes of 2010-2/ 2011-1 Dentistry graduate of the Universidade Federal do Rio Grande do Sul, classes of 2010-2/2011-1. It has been recommended that there be a permanent follow up of the graduates as an important instrument for monitoring the students as well as the development of the current integrated curriculum.

Indexing terms: Dental education. Dentistry. Higher Education.

\section{RESUMO}

\section{Objetivo}

Analisar o perfil sociodemográfico dos formandos em Odontologia na Universidade Federal do Rio Grande do Sul, 2010-2011, os motivos que os levaram a optar pela Odontologia, satisfação com o curso, bem como perspectivas de trabalho e de pós-graduação.

\section{Métodos}

Estudo transversal observacional com formandos em Odontologia, turmas 2010-2/ 2011-1 ( $n=76$, taxa de resposta 90,5\%). Coleta de dados aconteceu pela aplicação de questionário pré-testado, estruturado e anônimo. Resultados foram agrupados em tabelas e gráficos por meio da distribuição de frequência das variáveis investigadas (análise descritiva), com auxílio do programa Statistical Package for the Social Sciences (SPSS) para Windows versão 17.0. Estudo aprovado pelo Comitê de Ética em Pesquisa da Universidade Federal do Rio Grande do Sul (18249).

\section{Resultados}

Os formandos em Odontologia da Universidade Federal do Rio Grande do Sul, turmas 2010-2/2011-1, eram, em sua maioria, mulheres, jovens, solteiros, sem filhos, naturais do estado do Rio Grande do Sul, com renda familiar mensal de 10 a 20 salários mínimos e sem a presença de dentistas na família. Mais de $90 \%$ desses estudantes estavam satisfeitos com a opção pela Odontologia. Optaram pelo curso especialmente pela realização pessoal e profissional, seguida pela segurança e tranquilidade no futuro, posição social e conforto financeiro. A maior parte dos estudantes avaliou o curso como bom ou ótimo. Pretendem, em sua maioria, trabalhar tanto no serviço público quanto no privado e fazer pós-graduação, principalmente especialização.

\section{Conclusão}

Resultados identificaram o perfil do formando em Odontologia da Universidade Federal do Rio Grande do Sul, turmas 2010-2/2011-1. Recomenda-se o acompanhamento permanente dos formandos como importante instrumento de monitoramento tanto dos estudantes quanto do desenvolvimento do currículo integrado vigente.

Termos de indexação: Educação em Odontologia. Odontologia. Educação superior.

\footnotetext{
${ }^{1}$ Universidade Federal do Rio Grande do Sul, Faculdade de Odontologia. Porto Alegre, RS, Brasil.

${ }^{2}$ Universidade Federal do Rio Grande do Sul, Faculdade de Odontologia, Departamento de Odontologia Preventiva e Social. Rua Ramiro Barcelos, 2492 , Caixa Postal 1118, 90035-003, Porto Alegre, RS, Brasil. Correspondência para / Correspondence to: RFC TOASSI. E-mail: <ramona.fernanda@ufrgs.br>.
} 


\section{INTRODUCTION}

For a long period of time, the education of human resources in Dentistry in Brazil was directed almost exclusively at private practice of the profession in offices and private clinics, having individualized attention profile, high costs and an excessively technical character. On the other hand, an ever greater number of new Schools of Dentistry contrasted with a national scene of high indexes of pervasiveness of dental cavities, periodontal disease, occlusopathies and edentulous individuals ${ }^{1-2}$.

Such an inadequacy of the dentistry practice had its origin in a type of disconnected action of defined priorities based on epidemiological, social, cultural and human criteria ${ }^{3-5}$.

Feuerwerker $^{6}$ whilst analyzing the state of the education of health professionals with regard to Ministry of Health problems, challenges, perspectives and proposals, argued that education should be directed to the most relevant problems of society, so that the choice of essential content would need to be based on epidemiological criteria and needs of the population.

Within this context, higher education in Brazil went through important changes as of the institution of National Curriculum Directives (NCD) for undergraduate courses in the area of health, including Dentistry? The NCD pointed out a paradigmatic change in the education of the generalist professional, critical, reflexive, and capable of team work and taking the social reality and the current health system in the country into consideration, in a regionalized and hierarchical reference and counter reference system ${ }^{8-10}$.

With the Directives there was as of the education of the graduates apt to care for the complete and humanized health, team work and a better understanding of the reality in which the population lives ${ }^{11}$.

In order to bring about the NCD fulfillment, nonetheless, it is necessary to redefine the role of higher education in the education of human resources connected with the Brazilian Health System ${ }^{12}$ and the permanent construction of the curriculum dealing, in a special mode, the change in the pedagogical project as well as in the curricular practices ${ }^{13}$. Thus, the debate regarding education in Dentistry in Brazil currently traverses, through the profile of the professional which is being molded in the universities.
Preoccupations of this nature guided the present research, which had the objective of analyzing the sociodemographic profile of the 2010 and 2011 Dentistry graduates at Universidade Federal do Rio Grande do Sul (UFRGS), the reasons which took them to choose Dentistry, appreciation for the course, as well as job prospects and Graduate studies. The intent of carrying out this study was to set up a continuous monitoring process of the profile of Dentistry graduates at UFRGS.

\section{METHODS}

A transversal observational Study was carried out in the School of Dentistry of Universidade Federal do Rio Grande do Sul (FO-UFRGS).

All of the students taking the last undergraduate semester in Dentistry, in the second semester of 2010 and the first semester of 2011, were invited to participate. The students need not be incoming from the same entrance examination, but they should be graduating in that semester. Those who did not sign the Term of Free and Informed Consent or who missed the questionnaire application were excluded from the study.

The collection of data took place by means of the application of a structured questionnaire, which had been pre-tested, was anonymous, composed of 40 questions; these had been divided into 4 blocks: Block 1 - Sociodemographic Profile of the Student, Block 2 - About the Dentistry Course, Block 3 - Professional acting at the end of undergraduate course and Block 4 - Graduate studies. The questionnaire was responded to by the students, in approximately 45 minutes.

A database containing the collected, digital information through the Statistical Package for the Social Sciences (SPSS) Windows 17.0 was created for the analysis of data. The frequency distribution of the variables researched were calculated.

A descriptive analysis for the analysis of the data was created and the results were grouped in tables and figures.

The research was initially approved by the Commission of Research of the School of Research and subsequently, by the Commission of Ethics in Research at UFRGS (n. 18249).

\section{RESULTS}

The results are presented in four blocks: sociodemographic profile of the students. 


\section{Socio-demographic Profile of the Students}

Out of the 84 students in the last semester of the classes of 2010-2 and 2011-1 UFRGS Dentistry course, 76 took part in the research. There was a response rate of $90.5 \%$. Out of these, the majority were women(55.3\%), young $(67.2 \%$ ages 23 to 25 years), single $(97.4 \%)$, childless (98.7\%), natives of Rio Grande do Sul (88,2\%), with a monthly family income of from 10 to 20 minimum salaries (53.9\%) and no having no dentists in the family (64.5\%) (Table 1).

Table 1. Distribution of the socio-demographic characterization of the Dentistry graduates at UFRGS (2010-2011)

\begin{tabular}{|c|c|c|}
\hline Variables & $\mathrm{n}$ & $\%$ \\
\hline \multicolumn{3}{|l|}{ Sex } \\
\hline Feminine & 42 & 55.3 \\
\hline Masculine & 25 & 32.9 \\
\hline Not informed & 9 & 11.8 \\
\hline \multicolumn{3}{|l|}{ Age (years) } \\
\hline 21 to 22 & 11 & 14.5 \\
\hline 23 to 25 & 51 & 67.2 \\
\hline 26 to 29 & 12 & 15.7 \\
\hline 30 to 34 & 2 & 2.6 \\
\hline \multicolumn{3}{|l|}{ Marital Status } \\
\hline Single to & 74 & 97.4 \\
\hline Married & 2 & 2.6 \\
\hline \multicolumn{3}{|l|}{ Children } \\
\hline Yes & 1 & 1.3 \\
\hline No & 75 & 98.7 \\
\hline \multicolumn{3}{|l|}{ Native State } \\
\hline Rio Grande do Sul & 67 & 88.2 \\
\hline Santa Catarina & 4 & 5.3 \\
\hline São Paulo & 2 & 2.6 \\
\hline Mato Grosso do Sul & 1 & 1.3 \\
\hline Distrito Federal & 1 & 1.3 \\
\hline Other Country (Uruguay) & 1 & 1.3 \\
\hline \multicolumn{3}{|l|}{ Family Income (in minimum salaries - sm)* } \\
\hline 3 to $5 \mathrm{sm}$ & 8 & 10.7 \\
\hline 6 to $9 \mathrm{sm}$ & 10 & 13.1 \\
\hline 10 to $15 \mathrm{sm}$ & 31 & 40.8 \\
\hline 16 to $20 \mathrm{sm}$ & 10 & 13.1 \\
\hline $30 \mathrm{sm}$ & 3 & 3.9 \\
\hline $40 \mathrm{sm}$ & 2 & 2.6 \\
\hline $50 \mathrm{sm}$ & 1 & 1.3 \\
\hline Not informed & 11 & 14.5 \\
\hline \multicolumn{3}{|l|}{ Dentist in the Family } \\
\hline Yes, parents or siblings & 12 & 15.8 \\
\hline Yes, aunts, uncles or cousins & 13 & 17.1 \\
\hline Yes, parents or siblings, aunts, uncles or cousins & 1 & 1.3 \\
\hline Yes, grandfather & 1 & 1.3 \\
\hline No & 49 & 64.5 \\
\hline Total & 76 & 100.0 \\
\hline
\end{tabular}

*Value of the minimum salary at the time of answering questionnaire: $R \$ 545.00$.
The parents of these students were in the majority of cases, married (63.2\%), having a Higher Education (59.2\% of the fathers and $65.8 \%$ of the mothers) and were working at the time of answering the questionnaires (75\% of the fathers and $65.8 \%$ of the mothers). For $61.8 \%$ of the students, the father was responsible for the greatest family earning (Table 2 ).

Table 2. Distribution of the Dentistry course graduates according to the variables related to the families. FO-UFRGS (2010-2011).

\begin{tabular}{|c|c|c|}
\hline Variables & $\mathbf{n}$ & $\%$ \\
\hline \multicolumn{3}{|l|}{ Civil status of parents } \\
\hline Married & 48 & 63.2 \\
\hline Divorced & 25 & 32.9 \\
\hline WidowerMidow & 1 & 1.3 \\
\hline Not informed & 2 & 2.6 \\
\hline \multicolumn{3}{|l|}{ Education of the Father } \\
\hline Elementary Education incomplete & 2 & 2.7 \\
\hline Elementary Education complete & 1 & 1.3 \\
\hline High School Education complete & 13 & 17.1 \\
\hline Higher Education incomplete & 12 & 15.8 \\
\hline Higher Education complete & 45 & 59.2 \\
\hline Technical Course & 3 & 3.9 \\
\hline \multicolumn{3}{|l|}{ Education of the Mother } \\
\hline Elementary Education incomplete & 2 & 2.6 \\
\hline Elementary Education complete & 2 & 2.6 \\
\hline High School Education incomplete & 1 & 1.3 \\
\hline High School complete & 12 & 15.9 \\
\hline Higher Education incomplete & 7 & 9.2 \\
\hline Higher Education complete & 50 & 65.8 \\
\hline Technical Course & 1 & 1.3 \\
\hline Not Informed & 1 & 1.3 \\
\hline \multicolumn{3}{|l|}{ Situation of the Father in the job market } \\
\hline Is employed & 57 & 75.0 \\
\hline Is unemployed & 1 & 1.3 \\
\hline Is retired & 15 & 19.8 \\
\hline Deceased & 3 & 3.9 \\
\hline \multicolumn{3}{|l|}{ Situation of the Mother in the job market } \\
\hline Is employed & 50 & 65.8 \\
\hline Is unemployed & 3 & 3.9 \\
\hline Is retired & 15 & 19.8 \\
\hline Deceased & 2 & 2.6 \\
\hline Is retired, but still working & 6 & 7.9 \\
\hline \multicolumn{3}{|l|}{ Responsible for greatest family earning } \\
\hline Father & 47 & 61.8 \\
\hline Mother & 14 & 18.6 \\
\hline Husband or Wife & 3 & 3.9 \\
\hline Father and Mother earned the same amount & 9 & 11.8 \\
\hline Did not know & 3 & 3.9 \\
\hline Total & 76 & 100.0 \\
\hline
\end{tabular}


The students did not pass the first Dentistry entrance examination prior to admission (68.5\%) and the majority $(60.6 \%)$ entered the course at age 16 to 19 years.

Dentistry at UFRGS was the first undergraduate course for 88 . $2 \%$ of the students. Out of the students who began other courses, these were in the areas of Administration, Biology, Accounting, Engineering, Geography, Physics, Holism, Nutrition and Pedagogy.

\section{Regarding the Dentistry Course}

The majority of $(92.1 \%)$ the students, graduates of the FO-UFRGS in 2010 and 2011 seemed happy with their Dentistry choice. The reasons that made them opt for the profession were personal and professional satisfaction, followed by security and peace of mind in the future, social position and financial comfort (Figure 1).

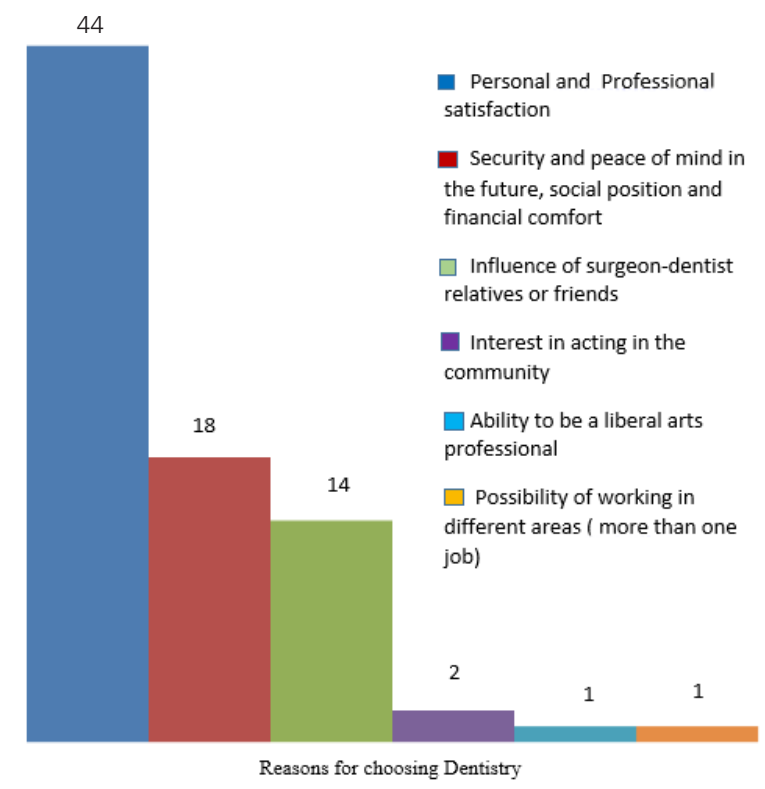

Figure 1. Distribution of the responses of the graduates regarding the reasons for opting in favor of the Dentistry course at FO-UFRGS (2010-2011).

Few students mentioned failure $(9.2 \%)$ or withdrawal from registration in the course for some time (6.6\%). This withdrawal from the course, when it occurred, was due to traveling (4\%), to personal reasons (1.3\%) and because they were not sure if they really liked the course $(1.3 \%)$. The time of withdrawal was for 1 or 2 semesters.

The great majority of the students (96.1\%) acknowledged having taken part in assistantships, extension projects and/or research during undergraduate studies and $71.1 \%$ received payment for the activity.

The students evaluated the undergraduate UFRGS Dentistry course as good (61.8\%), excellent (27.6\%) and average (6.6\%) and with regards to the 5 year undergraduate course, $82.9 \%$ of the students found the time adequate.

\section{Professional action at the end of undergraduate course}

After graduating $6.6 \%$ intend to act in the public service as well as in private (Table 3). When asked if they would devote 40 hours a week working on an Oral Health Team in the Family Health Strategy, $72.4 \%$ of the students said "no".

Table 3. Distribution of the graduates regarding the intended labor connection. School of Dentistry. FO -UFRGS (2010-2011).

\begin{tabular}{lcc}
\hline Variables & $\mathbf{n}$ & $\mathbf{\%}$ \\
\hline Intentions of job liaison & & \\
Only in private sector & 13 & 17.1 \\
Public and Private & 43 & 56.6 \\
Private and University & 4 & 5.3 \\
Public, private and University & 15 & 19.7 \\
Not informed & 1 & 1.3 \\
Acting in Family Health Strategy (40 hours) & & \\
Intends to & 18 & 23.7 \\
Does not intend to & 55 & 72.4 \\
Not informed & 3 & 3.9 \\
\hline Total & $\mathbf{7 6}$ & $\mathbf{1 0 0 . 0}$ \\
\hline
\end{tabular}

The reasons which would lead students to work only in the private sector were professional independence and better work conditions. With regard to choice of work in the public as well as the private sector, the reasons pointed out by the students were a secure income and the experience in the first professional years until setting up an office of building up clients, financial stability and assistance to the community.

Out of the 44 students who did not live in Porto Alegre upon entering UFRGS Dentistry course, only 20.5\% declared they had the intension of returning to their native city.

At the end of undergraduate studies, the expectation in terms of financial return for $42.1 \%$ of the students was of earning 11 to 20 minimum salaries (from $R \$ 5,995.00$ to $R \$ 10,900.00$ ), for $26.3 \%$ more than 20 minimum salaries (more than $R \$ 10,900.00$ ), for $25 \%$ from 6 to 10 minimum salaries (from $R \$ 3,270.00$ to $R \$ 5,450.00)$. Nearly $5 \%$ of the students said they did not know how much they intend to earn after the end of undergraduate studies. Only one student reported expecting to have a personal income of from 2 to 5 minimum salaries (from $R \$ 1,090.00$ to $R \$ 2,725.00$ ). 


\section{Graduate Studies}

The great majority of students (96.1\%) intends to take graduate courses, particularly specialization (57.9\%), for a period of from 6 months to 2 years (84.4\%) (Table 4).

Table 4. Distribution of graduate according to pretensão pela realização de cursos de Graduate Studies. FO-UFRGS (2010-2011).

\begin{tabular}{lcc}
\hline Variables & $\mathbf{n}$ & \% \\
\hline Graduate Studies & 73 & 96.1 \\
Yes & 1 & 1.3 \\
No & 2 & 2.6 \\
Did not inform & & \\
Up to what level do you intend to specialize? & 44 & 57.9 \\
Graduate Studies (specialization - professional & & \\
clinical practice) & 9 & 11.9 \\
Graduate Studies (mestrado e doutorado) & 16 & 21.1 \\
Specialization (professional clinical practice) e & & \\
mestrado e doutorado & 1 & 1.3 \\
Does not intend to specialize & 6 & 7.8 \\
Did not inform & \multicolumn{2}{c}{} \\
Period of time for Graduate Studies & 17 & 22.4 \\
Up to 6 months after undergraduate course & 22 & 29.0 \\
Up to 1 year after undergraduate course & 25 & 33.0 \\
Up to 2 years after undergraduate course & 5 & 6.5 \\
Up to 3 years after undergraduate course & 1 & 1.3 \\
Does not intend to specialize & 6 & 7.8 \\
Did not inform & $\mathbf{7 6}$ & $\mathbf{1 0 0 . 0}$ \\
\hline Total & & \\
\hline
\end{tabular}

The students the greatest interest in the areas of Prosthesis/Implantology, Surgery and Orthodontics. Collective Health was the fourth most mentioned area, along with Restorative Dentistry. Underlined is the fact that 15 of the 76 students still did not inform the area of interest (Figure 2).

\section{DISCUSSION}

The last semester students of the classes of 20102 and 2011-1 of the Dentistry course at UFRGS were, in their great majority, women, young, single, childless and natives of the state of the University where they were carrying out their undergraduate studies. Those same characteristics were identified in studies regarding the profile of Dentistry students in Brazil ${ }^{14-19}$.

The high percentage of women verified among the graduates $(55,3 \%)$ confirm the feminization process of the professions of the health area and, more especially, in Dentistry, throughout the years ${ }^{14-21}$. This standing out of women in Dentistry was also noticed in the international setting ${ }^{22-23}$.

Generally speaking, the predominance of female dentists was observed since the end of the '90's, whereas prior to that, the profession was considered eminently masculine, since $90 \%$ of the professionals were men $^{24}$.

Research regarding the current profile and tendencies of the Brazilian surgeon-dentist developed by Morita et al. ${ }^{25}$ corroborates this tendency. According to the authors, the profile of the Brazilian surgeon-dentist shows women are a majority in the young age brackets in 25 of the 27 states of Brazil, while men are in the majority, in the age brackets above 56 years, a fact which can be associated with the professional profile of dentists during the last decades, currently making up $56 \%$ of the total of professionals.

Matos et al. ${ }^{26}$ discussed the feminization of the health occupations and professions on approaching tendencies and concerns in the Brazilian context. They note that women make up the greatest part of students in higher education in the health area, even in those

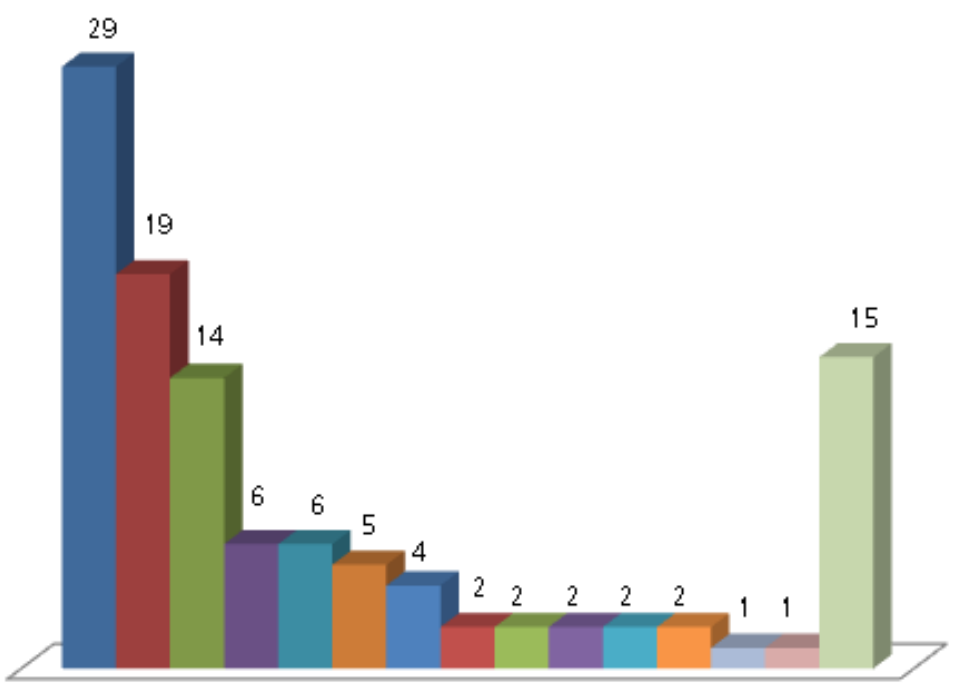

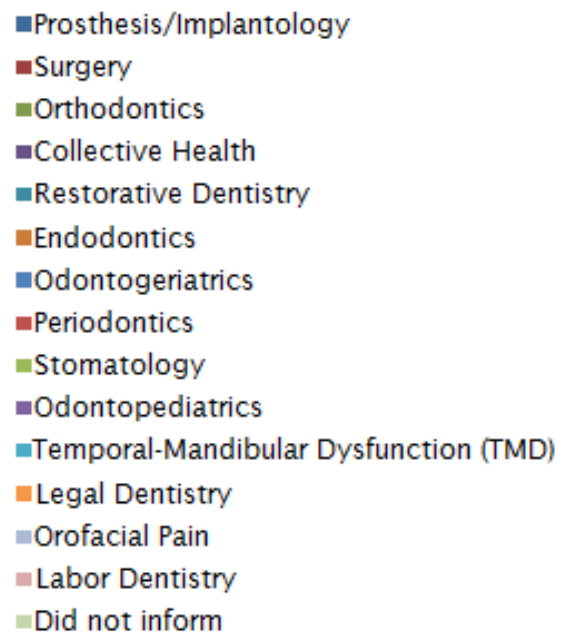

Figure 2. Distribution of the answers of the graduates regarding area of interest in Graduate studies. FO -UFRGS (2010-2011). 
historically masculine ones such as medicine and Dentistry.

With regard to the age of those students, the fact of being young graduates is related to the age at which they entered the Dentistry course at UFRGS (60.6\% were 16 to 19 years), to the low percentage of failures (9.2\%) and closing registration (6.6\%) observed, as described by Brustolin et al. ${ }^{15}$, in Dentistry students en Santa Catarina.

The socio economic level of the families of last semester students of Dentistry at UFRGS is considered high upon analyzing the monthly family income, the high education of the parents, the insertion of the parents in the job market and the access to dental care described by the greater part of the students. Added to that, many students (71.1\%) had some type of income during undergraduate studies related to scholarships covered by the Universidade Federal itself (assistantships, extension projects and/or research). A similar result was identified in the study with entering and graduating students at the Dentistry School at Araraquara ${ }^{16}$, where 51.2\% of the graduates received scholarships during the course.

Surgeon-dentists in the family were observed in $34.2 \%$ of the graduating students at the School of Dentistry at UFRGS. This value was very different from that found in 1992 by Slavutzky et al. ${ }^{27}$ among the students of the first year of Dentistry at UFRGS, where $94 \%$ of the students had relatives who were dentists.

According to the students, choosing Dentistry as a profession was determined principally through the personal and professional satisfaction, security/peace of mind in the future due to social position/financial comfort and the influence of dentists who were relatives or friends. The study of Brustolin et al. ${ }^{15}$, in Santa Catarina, pointed out beside personal and professional satisfaction, security/peace of mind in the future due to social position/financial comfort due to the issue of the interest of the students in acting in the community. In 2002, at UFRGS, Slavutzky et al. ${ }^{28}$ observed that $47 \%$ of the students chose Dentistry due to its being a liberal Arts profession and $28 \%$ because of vocation, similar to the study of Junqueira et al. ${ }^{19}$ in the Universidade Estadual Paulista Júlio de Mesquita Filho (UNESP SP). At Universidade Federal da Paraíba ${ }^{11}$ the students chose Dentistry principally through interest in the health area (50.6\%). The same thing was observed by Unfer et al. ${ }^{17}$ at Universidade Federal de Santa Maria (RS), Pontifícia Universidade Católica do Rio Grande do Sul and Costa et al. ${ }^{29}$ at Universidade Estadual de Montes Claros (MG).

Regarding satisfaction with the course, the majority of the Dentistry students at UFRGS in the last semester showed themselves to be satisfied with the choice of profession and evaluated the course as either good or excellent. They considered the time of five years for undergraduate studies as adequate for the education of a surgeon-dentist.

Satisfaction takes on a relevant role in the student evaluation of courses of higher education as of the reality perceived. The evaluation, through satisfaction, should be taken into consideration intensely in the undergraduate Dentistry courses, in part, because it is believed that satisfaction with the choice of profession and with the undergraduate course, makes placement easier in the job market, generating optimism in the students.

At UFRGS, after graduating, more than half of the students $(56.6 \%)$ declared they intend acting in the public service as well as in the private practice. The intention of the graduates of reconciling work in the public service with the private sector was similar to that found in the literature consulted $^{14-15}$. It is underscored that at Universidade Federal da Paraíba ${ }^{11}$ that percentage reached $88.4 \%$.

The comparison is interesting with the study of Slavutzky et al. ${ }^{28}$, also with the Dentistry students at UFRGS, which found that $57 \%$ of the students intended self-employment, in a private office, evincing Dentistry as a liberal arts profession, quite connected to the private sector. Among the 2010/2011 graduates, who went through an integrated curriculum based on the NCD proposal, an important change tendency was observed with regard to job perspective. The $57 \%$ of students which intended to work only in a private office in 2002 dropped to $17.1 \%$ in 2010/2011, evincing a tendency of change in the practice intention of professional acting.

The exclusive practice in a private office is no longer established as a practice for the majority of the graduates. Such a situation may have been influenced by the important and needed change connected to the policies of Education and Health in the country ${ }^{4}$.

When the National Curricular Directives were established for the undergraduate courses of health, including Dentistry ${ }^{7}$, there was a new direction of the graduation process in search of a new professional profile to be educated in Brazil. The education of health professionals and of the surgeon-dentist began to look at the Health System in force, at the time, in the country and be a pivot point so that the Sistema Único de Saúde (SUS) could fulfill the objectives it set out to reach, within its fundamental principles of universality, completeness, equity and social control $^{10}$. In addition to that, great advances were observed in public health policies in Brazil regarding the redirection of the work process with the inclusion of Oral Health in the Family Health Strategy and 
through the priority given by the current federal to the public health Policy 'Brasil Sorridente'2.

In the Dentistry course at UFRGS, in a special manner, the curricular change and the implantation of the new pedagogical project based on the NCD took place in 2005 , foreseeing the change of profile of the graduating professional, who should further, preserve and recuperate the health of the population, guided by the principles of ethics and bioethics. The surgeon-dentist educated by UFRGS as of the curricular change should be a generalist endowed with a social vision of reality, caring for his patient as a bio-psycho-socio-cultural individual ${ }^{30}$.

It is underlined, however, that the reasons which led the students to opt, in great part, for a connection with public service as well as private was the possibility of having secure income as well as experience during the first professional years, until setting up an office or building a clientele. The students from these groups, in the same way, did not identify themselves as workers of a Dental Health Team in the Family Health Strategy, with a SUS 40 hours a week connection. The choice for working in a private office was motivated principally because of self-employment or better wok conditions. Among the Dentistry students in Santa Catarina ${ }^{15}$, self-employment followed by profit and stability were the reasons which were most pointed out.

Preference for Graduate Studies was observed by the majority of Dentistry students at UFRGS, which agrees with findings of the literature ${ }^{15-16}$. The areas of greatest specialization interest were Prosthesis/Implantology, followed by Surgery, Orthodontics, Collective Oral Health and Dentistry. It is underlined that the appearance the Collective Oral Health specialty, was an area which was not mentioned in other national studies ${ }^{15,19}$.

Finally, it is necessary to underline that the results presented regarding the profile of the student who is graduating in Dentistry at UFRGS refer to a short period of time (a year of monitoring), with the first groups (third and fourth) which concluded the course within the new curricular proposal. The continuous monitoring of those students is necessary for setting up the profiles of the Dentistry graduate at UFRGS.

\section{REFERENCES}

1. Morita MC, Kriger L, Carvalho ACP, Haddad AE. Implantação das diretrizes curriculares nacionais em odontologia. Maringá: Dental Press; 2007.

2. Garbin D, Mattevi GS, Carcereri D, Caetano JC. Odontologia e saúde suplementar: marco regulatório, políticas de promoção

\section{CONCLUSION}

The results found allowed for the identification of the profile of the 2010-2 and 2011-1 groups of Dentistry graduates at UFRGS, as being in their majority women, young, single, childless from the state of origin of the University where they were carrying out their undergraduate studies, with a monthly family income of 10 to 20 minimum salaries and no dentists in the family. Their parents had a high level of education and they were inserted in the job market. These students did not pass the first entrance examination and were very young when they entered the course. More than $90 \%$ appeared to be satisfied with their choice of Dentistry. The reasons which took them to opt for the profession were personal and professional satisfaction, followed by security and peace of mind, social position and financial comfort. Few students mentioned failure or closing registration in the course. The great majority of the students evaluated the undergraduate course in Dentistry at UFRGS as good or excellent and considered the time of five undergraduate years as adequate. The showed the intention of allying public and private service in professional acting, in addition to the intention of undertaking Graduate Studies, especially specialization.

It has been recommended that permanent monitoring of the profile of Dentistry graduates at UFRGS be adopted as an important instrument be set in place with the students as well as with the integrated curricular development in force in the course.

\section{Collaborators}

F BÖCKMANN, B MOTTA, J CAMARGO were responsible for the construction of the research project and they took part in the search, organization and analysis of data and writing of the article. PC PETRY contributed to the reading and writing of the article. RFC TOASSI was responsible for the direction of research, data search, organization and analysis of data and writing of the article.

da saúde e qualidade da atenção. Ciênc. Saúde Coletiva. 2013;18(2):441-52. doi: 10.1590/S1413-81232013000200015

3. Pinheiro FMC, Nóbrega-Therrien SM, Almeida MEL, Almeida Ml. A formação do cirurgião-dentista no Brasil: contribuições de estudos para a prática da profissão. RGO, Rev Gaúch Odontol. 2009;57(1):99-106.

4. Morita MC, Haddad AE. Interfaces da área da educação e da saúde na perspectiva da formação e do trabalho das equipes 
de saúde da família. In: Moysés ST, Kriger L, Moysés SJ (Coord.). Saúde bucal das famílias: trabalhando com evidências. São Paulo: Artes Médicas; 2008. p. 268-76.

5. Conrado CA, Gomes GS, Robazza CR. O projeto pedagógico: estruturação e desenvolvimento curriculares - o currículo multidisciplinar integrado. In: Terada RSS, Nakama L. A implantação das diretrizes curriculares nacionais de odontologia: a experiência de Maringá. São Paulo: Hucitec; 2004.

6. Feuerwerker LCM. Educação dos profissionais de Saúde hoje: problemas, desafios, perspectivas e as propostas do Ministério da Saúde. Rev ABENO. 2003;3(1):24-7.

7. Brasil. Conselho Nacional de Educação. Câmara de Educação Superior. Resolução CNE/CES n. 3, de 19 de fevereiro de 2002. Institui as Diretrizes Curriculares Nacionais do Curso de Graduação em Odontologia. Brasília: Diário Oficial da União; 2002, 4 de março [citado 2013 Nov 11]. Disponível em: <http:// portal.mec.gov.br/cne/arquivos/pdf/CES032002.pdf>.

8. Morita MC, Kriger L. Mudanças nos cursos de Odontologia e a interação com o SUS. Rev ABENO. 2004;4(1):17-21.

9. Saliba NA, Moimaz SAS, Garbin CAS, Diniz DG. Dentistry in Brazil: its history and current trends. J Dent Educ. 2009;73(2):225-31.

10. Freitas SFT, Calvo MCM, Lacerda JT. Saúde coletiva e novas diretrizes curriculares em odontologia: uma proposta para graduação. Trab Educ Saúde. 2012;10(2):223-34. doi: 10.1590/ S1981-77462012000200003.

11. Cavalcanti YW, Cartaxo RO, Padilha WWN. Educação odontológica e Sistema de Saúde brasileiro: práticas e percepções de estudantes de graduação. Arq Odontol. 2010;46(4):224-31.

12. Araújo ME. Palavras e silêncio na educação superior em Odontologia. Ciênc Saúde Coletiva. 2006;11(1):179-82. doi: $10.1590 / 51413-81232006000100026$

13. Toassi RFC, Stobäus CD, Mosquera JJM, Moysés SJ. Currículo integrado no ensino de Odontologia: novos sentidos para a formação na área da saúde. Interface Comun Saúde Educ. 2012;16(41):529-42.

14. Toassi RFC, Souza JM, Rösing CK, Baumgarten A. Perfil sociodemográfico e perspectivas em relação à profissão do estudante de odontologia da Universidade Federal do Rio Grande do Sul, Brasil. Rev Fac Odontol Porto Alegre. 2011;52(1):25-32.

15. Brustolin J, Brustolin J, Toassi RFC, Kuhnen M. Perfil do acadêmico de odontologia da Universidade do Planalto Catarinense - Lages - SC, Brasil. Rev ABENO. 2006;6(1):70-6.

16. Loffredo LCM, Pinelli C, Garcia PPNS, Scaf G, Camparis CM. Característica socioeconômica, cultural e familiar de estudantes de Odontologia. Rev Odontol UNESP. 2004;33(4):175-82.

17. Unfer B, Rigodanzo L, Hahan D, Manfredini D, Rodrigues E, Cavalheiro $\mathrm{CH}$. Expectativas dos acadêmicos de odontologia quanto à formação e futura profissão. Saúde. 2004;30(1-2):33-40.
18. Nicodemo D, Naressi WG. O perfil do aluno de odontologia: do ingresso à sua graduação. Rev Odonto Ciênc. 2002;17(36):135-9.

19. Junqueira JC, Colombo CED, Tavares PG, Rocha RF, Carvalho $Y R$, Rodrigues JR. Quem é e o que pensa o graduando de odontologia. Rev Odontol UNESP. 2002;31(2):269-84.

20. Freire MCM, Jordao LMR, Ferreira NP, Nunes MF, Queiroz MG, Leles CR. Motivation towards career choice of Brazilian freshman students in a fifteen-year period. J Dent Educ. 2011;75(1):115-21.

21. Costa SM, Durães SJA, Abreu MHNG. Feminização do curso de odontologia da Universidade Estadual de Montes Claros. Ciênc Saúde Coletiva. 2010;15(1):1865-73. doi: 10.1590/S141381232010000700100 .

22. Al-Bitar ZB, Sonbol HN, Al-Omari IK. Reasons for choosing dentistry as a career by Arab dental students. Eur J Dent Educ. 2008;12(4):247-51 doi: 10.1111/j.1600-0579.2008.00526.x.

23. Hallissey JH, Hannigan A, Ray N. Reasons for choosing dentistry as a career - a survey of dental students attending a dental school in Ireland during 1998-99. Eur J Dent Educ. 2000; 4(2):77-81. doi: 10.1034/j.1600-0579.2000.040205.x.

24. Funk PP, Flôres MMDZ, Garbin CA, Hartmann MSM, Mendonça JL. Perfil do profissional formado pela Faculdade de Odontologia da Universidade de Passo Fundo/RS: da formação à realidade profissional. RFO UPF. 2004;9(2):105-9.

25. Morita MC, Haddad AE, Araujo ME. Perfil atual e tendências do cirurgião-dentista brasileiro. Maringá: Dental Press; 2010.

26. Matos IB, Toassi RFC, Oliveira MC. Profissões e ocupações de saúde e o processo de feminização: tendências e implicações. Athenea Digital. 2013;13(2):239-44.

27. Slavutzky SMB, Bercht S, Lima LS. Perfil do calouro odontologia. Rev Fac Odontol Porto Alegre. 1992;33(2):13-5.

28. Slavutzky SMB, Abegg C, Gross RF, Rosa MAC. Mercado de trabalho: perfil do acadêmico de odontologia da Universidade Federal do Rio Grande do Sul. Rev Fac Odontol Porto Alegre. 2002;43(2):3-6.

29. Costa SM, Durães SJA, Abreu MHNG, Bonan PRF, Vasconcelos M. Motivos de escolha da Odontologia: vocação, opção ou necessidade? Arq Odontol. 2010;46(1):28-37.

30. Universidade Federal do Rio Grande do Sul. Faculdade de Odontologia. Projeto Político Pedagógico. Porto Alegre, 2005 [acesso 2013 nov 11]. Disponível em: <http://www.ufrgs.br/ odonto/projeto_pedagogico_odontologia_curso_diurno>.

Received on: 29/7/2013

Final version resubmitted on: 18/11/2013 Approved on: 7/7/2014 